\title{
THE ROLE OF LOCAL GOVERNMENT IN REALIZING SUSTAINABLE MARINE TOURISM IN PEMUTERAN VILLAGE GEROKGAK SUB DISTRICT BULELENG BALI PROVINCE
}

\author{
Ni Made Gandhi Sanjiwani. \\ Postgraduate School of Universitas Gadjah Mada. \\ Yogyakarta, Indonesia. \\ md.gandhi.s@mail.ugm.ac.id
}

\begin{abstract}
This paper aims to study the role of local government in realizing sustainable marine tourism. Pemuteran Village is one of the best practices of sustainable marine tourism in the developing world. Three types of government roles were studied, namely: regulator, facilitator, and executor. These roles were positioned as exogenous latent variables in a causal relationship with sustainable marine tourism in the village. Sustainability is measured through reflective constructs, i.e., economic benefit, socio-cultural benefit, and environmental benefit felt by the local community of Pemuteran Village. The data were collected from 60 respondents, consisting of community leaders, non-governmental organizations, and tourism industry stakeholders in Pemuteran Village. Then, questionnaires were analyzed by structural equation modelling - partial least square (path modelling). The results show that government roles did not have a significant effect on marine tourism sustainability. However, the role of local government and the existence of marine tourism sustainability were reflected significantly in its three constructs where the most represented construct in this relationship respectively are the role of facilitator and the environmental benefit. The most important finding in this research is that the role of local government was not only measured by regulator and facilitator roles, as in previous research, but includes analysis of the executor role which proved significant in structural model evaluation.
\end{abstract}

KEYWORDS: The Role of Local Government, Sustainable Marine Tourism, Partial Least Square (Path Modelling), Pemuteran Village.

\section{INTRODUCTION}

Tourism is a very important part of the economic development strategies in various developing countries (Birkiè, Pilija, \& Šebrek, 2014:2; UNWTO, 2017; WTTC, 2017). In line with this idea, marine tourism is one of the fastest growing 
areas, within the world's largest industry (Hall, 2001). In Indonesia, the growth of marine tourism has been rapid, as indicated by the high demand for related products. In 2013 , up to $12.25 \%$ of total travel to Indonesia was directly related to marine tourism (Destination Field Research, 2015) In Bali, the growth of the marine tourism industry has spread to almost all regions. This is because Bali has a part of the world's largest reef triangle, containing the richest coral species, where Buleleng region has the longest coastal area. This means Buleleng region has a very diverse marine tourism potential among other regions. In Buleleng, Pemuteran is a village with high potential to become a marine tourism-based village (disbudpar.bulelengkab.go.id).

The importance of the marine tourism potential in Pemuteran Village has made it a National Tourism Strategic Destination or "Kawasan Strategies Pariwisata Nasional (KSPN)," becoming the focus and development priorities in 2016(www.kemenpar.go.id). Today, the success of the artificial reef program in Pemuteran has become a shining example of sustainable marine tourism development throughout the world (Destination Field Research 2015; Indonesia Tourism Ministry, 2017).

Destination Field Research (2015) found that the development of marine tourism in Pemuteran Village applied the principle of sustainability, but there are still social-cultural and environmental costs borne by the local community. Other problems are faced by society, such as the lack of public facilities and infrastructure, waste problems due to poor management, and the lack of operational funds in regards to coral reef security in Pemuteran Village.

In an attempt to achieve sustainable tourism in Bali, including Pemuteran Village, government roles become very important. The central and local governments have a strategic function to frame policies that that direct industry and local communities to develop tourism in Bali. Those roles can be implemented by incentivizing the tourism industry, motivating the development of business in a healthy and competitive atmosphere. Moreover, the government also has an important role in building infrastructure for the region, ensuring the quality of tourist attractions. The role of improving Bali's human resources in tourism development is also the responsibility of local and central governments through preparing the human resource developing program and also by providing the budget (Mertha., et al., 2015).

The local government has an indispensable role in the development of a tourism destination, because: (a) The tourism industry has a variety of factors (externalities) that are negative, especially in social and environmental impacts; (b) Industry to provide opportunities that can be directed to promote economic growth. (Ogechi and Igbojekwe, 2012: Markandya et al., 2003, p.84 in Mertha, 2015; UNEP, 2003). During this time, little attention has been given to research by academics to understand the roles and responsibilities of local authorities about sustainable tourism development (Dinica, 2009; Wray, 2009; Beaumont \& Dredge, 2010 in Brokaj, 2014). As Doods \& Butler (2010) stated. Currently there is a great deal of research about tourism policy and a plethora of information on sustainable tourism, however on the implementation of tourism policy in general is weak and research on sustainable tourism policy is even more so. In this case, the roles of 
government as a regulator, facilitator, and executor are needed. For now, research that focuses on the role of local government in sustaining tourism development in Bali has not been conducted in a comprehensive manner (Mertha., et al., 2015). The purpose of the present study are as follows:

1. How do people in Pemuteran perceive the role of local government in the development of marine tourism in that region?

2. How does the role of local government influence the sustainability of marine tourism in Pemuteran Village?

\section{METHODOLOGY}

\subsection{Population, Sample, and Research Instrument}

The role of local government in the realization of sustainable marine tourism is assessed by public perception. Therefore, the population of this research was local people in Pemuteran Village of Buleleng, Bali, which is spread over nine Banjars or small parts of the village. The sample was selected by a quota sampling method, with 60 established respondents, consisting of community leaders (formal and nonformal positions), non-government organization members, and tourism industry stakeholders in Pemuteran Village. To measure the local people's perception of the role of local government in realizing sustainable marine tourism in their village, every respondent was given a closed statement questionnaire.

The collected data were analyzed quantitatively. A pilot test was conducted with 30 respondents to test the validity and reliability of the data. Validity and reliability are two components related to the precision of measurement tools. First, reliability is a measure of internal consistency, an indicator of explaining variables. A set of indicators have an internal consistency when Cronbach's Alpha coefficient $(\alpha)$ is greater than or equal to 0.7 . If research used the exploratory method the value of Cronbach's Alpha coefficient can be less than 0.7 but greater than or equal to 0.6 $\mathrm{d}$. The second criteria is validity, which refers to the ability of an indicator to explain a concept. The item is valid as an indicator if it has a correlation coefficient of at least 0.3 and a sign that is equal to the value of the other correlation coefficient (Mertha, 2015; Heale \& Twycross, 2015; Drost, 2011).

\subsection{Data Analysis}

To analyze the data of this study, two kinds of analysis were used: (a) descriptive analysis, which is used to see the description of data collected (b) quantitative analysis, which is used to see the correlation and the causal every variable in the model. As exogenous latent, the role of local government is viewed by its regulator, the facilitator, and executor role. As endogenous latent, the sustainability of marine tourism is viewed by its economic, sociocultural, and environmental benefits. Quantitative analysis was performed by utilizing Smart PLS (Partial Least Square) Program 3.0 (Wright, 1921; Haavelmo, 1943; Simon, 1953 in Jogiyanto \& Abdillah, 2014), that focuses on endogenous target 
constructs in the model and aims at maximizing their explained variance (i.e., their R2 value) (Hair, Ringle, Sarstedt, 2012). Conceptually, this study is depicted in Figure 1.

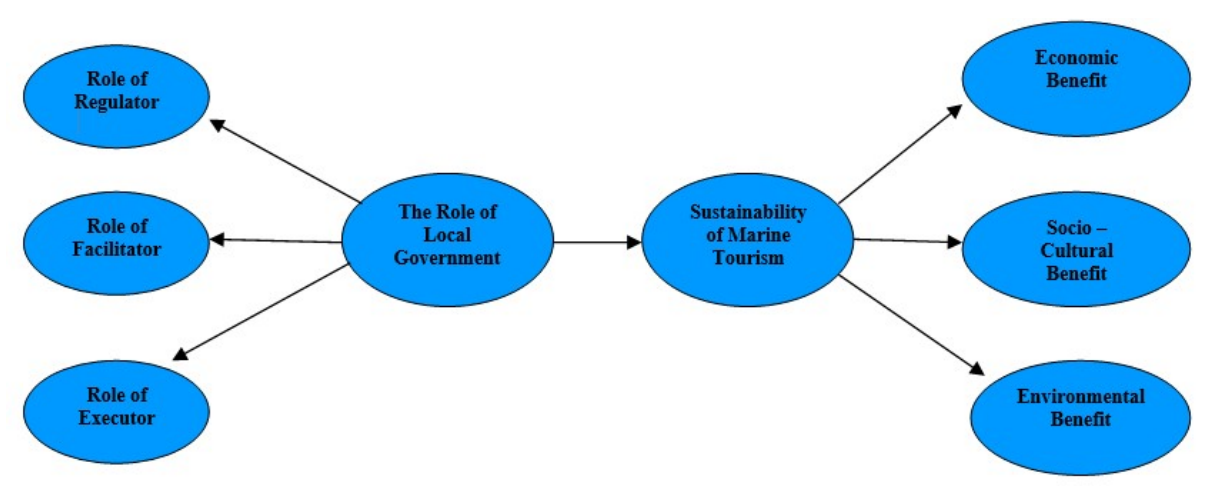

Figure 1: Research Conceptual Model

\section{RESULT AND DISCUSSION}

\subsection{Respondents Description}

The individual is the unit of analysis in this study; they are members of the local community in the village Pemuteran and across nine Banjars. Sixty questionnaires were distributed to respondents. All respondents are indigenous people from Pemuteran Village. Eighty-five percent of respondents have been living since birth in Pemuteran Village. These conditions provide an understanding that respondents are familiar with both the village and the community, qualifying them as able to explain about the condition of the region, government activities, as well as tourism development activities in their area.

Descriptively, 73.3 percent of respondents have completed high school; even 1.7 percent of them had a graduate degree. Most of the respondents were older (85 percent) than 24 years. Based on these characteristics (education level completed and ages) we concluded that their perception regarding local government roles toward the sustainability of marine tourism at their village could be trusted.

\subsection{Quality of Questionnaires}

The instrument used in this research was a closed-question questionnaire, and all of the items were measured using a Likert-type scale with five options. Before analyzing the data, we tested the validity of each statement and the reliability of the questionnaire, by observing the correlation coefficient and the value of coefficient alpha. Table 1 and Table 2 show the results: 
Table 1 Validity and Reliability Values of Indicators for Government Roles

\begin{tabular}{|c|c|c|c|}
\hline \multicolumn{4}{|c|}{ Indicators for Regulator Role } \\
\hline Code & Statements & Corr & $\begin{array}{l}\alpha \text { if item } \\
\text { deleted }\end{array}$ \\
\hline $\mathrm{X} 11$ & $\begin{array}{l}\text { Effective regulation has been made to protect the } \\
\text { local business from unfair business competition }\end{array}$ & 0.479 & 0.699 \\
\hline $\mathrm{X} 12$ & $\begin{array}{l}\text { The regulation has been made to facilitate business } \\
\text { license }\end{array}$ & 0.694 & 0.399 \\
\hline $\mathrm{X} 13$ & $\begin{array}{l}\text { Effective regulation has been made to create a } \\
\text { conducive business climate }\end{array}$ & 0.446 & 0.715 \\
\hline \multicolumn{3}{|c|}{ Alpha Cronbach } & 0.710 \\
\hline \multicolumn{4}{|c|}{ Indicators for Facilitator Role } \\
\hline Code & Statements & Corr & $\begin{array}{l}\alpha \text { if item } \\
\text { deleted }\end{array}$ \\
\hline $\mathrm{X} 21$ & $\begin{array}{l}\text { Local Government has helped local communities } \\
\text { in building infrastructure }\end{array}$ & 0.745 & 0.800 \\
\hline $\mathrm{X} 22$ & $\begin{array}{l}\text { Local Government has helped the community in } \\
\text { the development programs of human resources }\end{array}$ & 0.752 & 0.801 \\
\hline $\mathrm{X} 23$ & $\begin{array}{l}\text { Local Government has helped the community in } \\
\text { the form of mentoring program }\end{array}$ & 0.462 & 0.839 \\
\hline $\mathrm{X} 24$ & $\begin{array}{l}\text { Local Government has helped the community in } \\
\text { maintaining the damaged infrastructure }\end{array}$ & 0.680 & 0.811 \\
\hline $\mathrm{X} 25$ & $\begin{array}{l}\text { Local Government has helped the community in } \\
\text { obtaining education and health services }\end{array}$ & 0.548 & 0.828 \\
\hline $\mathrm{X} 26$ & $\begin{array}{l}\text { Local Government has helped the community in } \\
\text { providing financial assistance to support tourism } \\
\text { activities }\end{array}$ & 0.613 & 0.820 \\
\hline $\mathrm{X} 27$ & $\begin{array}{l}\text { Local Government has conducted consultations } \\
\text { regularly in decision making with the community } \\
\text { related to marine tourism }\end{array}$ & 0.314 & 0.853 \\
\hline $\mathrm{X} 28$ & $\begin{array}{l}\text { Local Government has helped the community in } \\
\text { promoting and marketing for marine tourism }\end{array}$ & 0.500 & 0.833 \\
\hline \multicolumn{3}{|c|}{ Alpha Cronbach } & 0.843 \\
\hline
\end{tabular}




\begin{tabular}{|l|l|l|c|}
\hline Code & \multicolumn{1}{|c|}{ Statements } & Corr & $\begin{array}{l}\alpha \text { if item } \\
\text { deleted }\end{array}$ \\
\hline X31 & $\begin{array}{l}\text { Local Government has ensured the regulation has } \\
\text { worked as it should }\end{array}$ & 0.634 & 0.877 \\
\hline $\mathbf{X 3 2}$ & $\begin{array}{l}\text { Local Government has given warning to the } \\
\text { community who do not obey the regulation }\end{array}$ & 0.852 & 0.672 \\
\hline $\mathbf{X 3 3}$ & $\begin{array}{l}\text { Local Government has given sanctions on any } \\
\text { violations of regulations related to marine tourism }\end{array}$ & 0.708 & 0.817 \\
\hline \multicolumn{1}{|c|}{ Alpha Cronbach } & $\mathbf{0 , 8 5 4}$ \\
\hline
\end{tabular}

Source: Primary Data, 2016

Table 1 shows that all three reflective constructs of local government roles examined are indicators, valid and reliable. This is shown by the average correlation coefficient value being above 0.3 with the value of Cronbach Alpha being, respectively $0.710 ; 0.843$; and 0.854 , which exceeds the required threshold value. From these values, we can conclude that government roles as a main latent variable in the model had sufficient alpha value and its indicators were valid reflections of the concept

Table 2. Validity and Reliability Values of Indicators for Sustainability Of Marine Tourism

\begin{tabular}{|l|l|l|c|}
\hline \multicolumn{1}{|c|}{ Indicators for Economic Benefits } & Corr & $\begin{array}{l}\boldsymbol{\alpha} \text { if item } \\
\text { deleted }\end{array}$ \\
\hline Code & \multicolumn{1}{|c|}{ Statements } & 0.718 \\
\hline Y11 & $\begin{array}{l}\text { Marine tourism activities positively increase the } \\
\text { household income of local community }\end{array}$ & 0.811 & 0.720 \\
\hline Y12 & $\begin{array}{l}\text { Marine tourism activities positively increase employment } \\
\text { opportunities for the local community }\end{array}$ & 0.851 & 0.720 \\
\hline Y13 & $\begin{array}{l}\text { Marine tourism activities positively increase local } \\
\text { business opportunities for the local community }\end{array}$ & 0.851 & 0.764 \\
\hline Y14 & $\begin{array}{l}\text { Marine tourism activities positively make communities } \\
\text { more easily meet the needs of life }\end{array}$ & 0.551 & 0.770 \\
\hline Y15 & $\begin{array}{l}\text { Marine tourism activities positively increase local } \\
\text { employment }\end{array}$ & 0.556 & 0.903 \\
\hline Y16 & $\begin{array}{l}\text { Marine tourism activities positively increase the quantity } \\
\text { and quality of health facilities }\end{array}$ & 0.299 & $\mathbf{0 . 7 9 5}$ \\
\hline
\end{tabular}




\begin{tabular}{|c|c|c|c|}
\hline \multicolumn{4}{|c|}{ Indicators for Socio-Cultural Benefit } \\
\hline Code & Statements & Corr & $\begin{array}{l}\alpha \text { if item } \\
\text { deleted }\end{array}$ \\
\hline Y21 & $\begin{array}{l}\text { Marine tourism activities positively increase efforts to } \\
\text { preserve local culture }\end{array}$ & 0.440 & 0.632 \\
\hline Y22 & $\begin{array}{l}\text { Marine tourism activities positively increase the quality } \\
\text { of education }\end{array}$ & 0.711 & 0.470 \\
\hline Y23 & $\begin{array}{l}\text { Marine tourism activities positively increase } \\
\text { appreciation and mutual respect for the existence of } \\
\text { cultural differences }\end{array}$ & 0.324 & 0.726 \\
\hline Y24 & $\begin{array}{l}\text { Marine tourism activities positively increase local } \\
\text { community's awareness to more protected and } \\
\text { preserved places purified according to Hindu religion }\end{array}$ & 0.451 & 0.625 \\
\hline \multicolumn{3}{|c|}{ Alpha Cronbach } & 0.682 \\
\hline \multicolumn{4}{|c|}{ Indicators for Environmental Benefit } \\
\hline Code & Statements & Corr & $\begin{array}{l}\alpha \text { if item } \\
\text { deleted }\end{array}$ \\
\hline Y31 & $\begin{array}{l}\text { Marine tourism activities positively increase } \\
\text { maintenance and conservation of coral reefs }\end{array}$ & 0.376 & 0.714 \\
\hline Y32 & $\begin{array}{l}\text { Marine tourism activities positively increase } \\
\text { conservation of physical beach and sea }\end{array}$ & 0.646 & 0.623 \\
\hline Y33 & $\begin{array}{l}\text { Marine tourism activities positively increase the } \\
\text { cleanliness of the surrounding environment }\end{array}$ & 0.472 & 0.682 \\
\hline Y34 & $\begin{array}{l}\text { Marine tourism activities positively increase } \\
\text { maintenance of public facilities }\end{array}$ & 0.387 & 0.748 \\
\hline Y35 & $\begin{array}{l}\text { Marine tourism activities positively increase } \\
\text { awareness on environmental sustainability }\end{array}$ & 0.686 & 0.616 \\
\hline \multicolumn{3}{|c|}{ Alpha Cronbach } & 0.723 \\
\hline
\end{tabular}

Source: Primary Data, 2016

Referring to values in Table 2, we decided to drop item Y16 from the reflective-indicator composer of economic benefits which its correlational value as much as 0.299 . Despite this, value actually can still be analyzed as it approaches 
the required threshold limit of 0.3, as specified by Churchill, Jr., (1979) in Merth (2015). This item was excluded, based on consideration of significant increment in latent's reliability (from 0.795 increase to 0.903 ) if this item was removed, so it was decided to excluded item Y16. By eliminating this indicator, a final operational model of our research is illustrated in Figure 2:

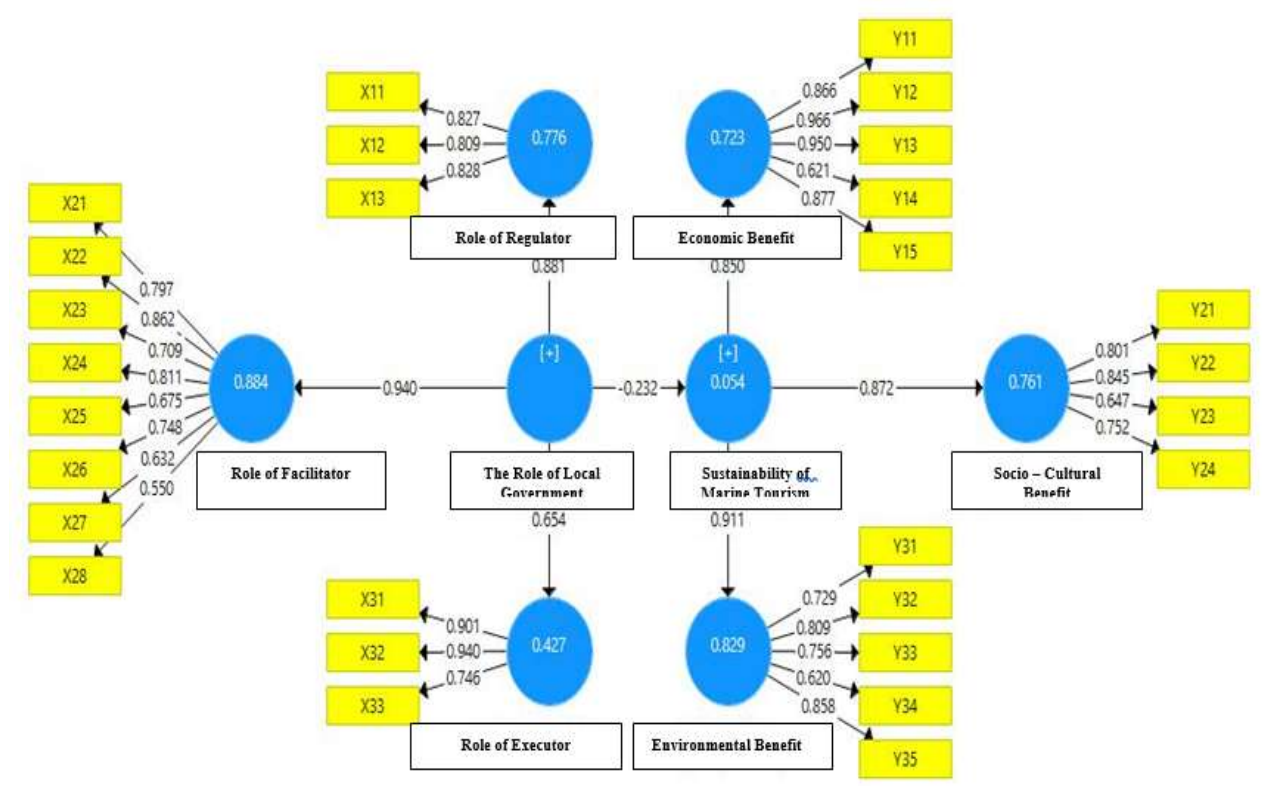

Figure 2: Final Operational Model

In structural equation model (SEM), according to Sarstedt et al. (2016) and Hair et al. (2012) two sub-analyses - outer or measurement models, and inner or structural models - must be conducted. The outer model focuses on the relationship that occurred between the latent and its indicator, while the inner model focuses on the causal relationships between the latent variables.

\subsection{Outer Model Analysis}

Outer model analysis can be seen from several indicators, namely: convergent validity, discriminant validity, and unidimensionality (the value of composite reliability). In SEM, convergent validity (CV) reflects the validity of items in a latent that have reflective properties. $\mathrm{CV}$ is examined through two types of measures: Average Variance Extracted (AVE) and the Composite Reliability (CR) value of latent with reflective items. Referring to the opinion of Hair et al., (2017) and Sarstedt et al., (2014), Sutton (2017) states that a latent with reflective items are considered to have a reliable $\mathrm{CV}$ when the value of $\mathrm{AVE}>0.5$ and $\mathrm{CR}$ value $>$ 0.7. In line with the requirements set forth by Hair et al., (2010) a measurement has met the convergent validity if it has a CR higher than 0.7 and an AVE of at least 0.5 . If any of the values are below the required threshold value, it is checking the value of the validity of the constituent items is recommended. Table 3 shows the 
Average Variance Extracted (AVE) value and Composite Reliability (CR) value for all of latent with it's the reflective indicator.

Table 3. Outer Model Evaluation for Main Latent with Its Reflective Indicator

\begin{tabular}{|c|c|c|c|c|c|}
\hline \multirow{2}{*}{ No } & \multirow{2}{*}{ Latent Variables } & \multirow{2}{*}{$\begin{array}{l}\text { Item } \\
\text { Total }\end{array}$} & \multicolumn{3}{|c|}{$\begin{array}{l}\text { Criteria for Convergent } \\
\text { Validity }\end{array}$} \\
\hline & & & AVE & CR & $\begin{array}{c}\text { Value } \\
\text { Information }\end{array}$ \\
\hline 1. & Economic Benefit & 5 & 0.748 & 0.936 & Very Good \\
\hline 2. & Socio-Cultural Benefit & 4 & 0.585 & 0.848 & Good \\
\hline 3. & Environmental Benefit & 5 & 0.576 & 0.870 & Good \\
\hline 4. & Regulator Role & 3 & 0.675 & 0.862 & Very Good \\
\hline 5. & Facilitator Role & 8 & 0.532 & 0.899 & Good \\
\hline 6. & Executor Role & 3 & 0.751 & 0.900 & Very Good \\
\hline
\end{tabular}

Source: Primary Data, 2016

Table 3. shows that all Composite Reliability (CR) values exceed the critical value of 0.70 as required by Sarstedt et al., in Sutton (2017). ThisIt means the measurement model is reliable. As well as the AVE values of these six sub-latent variables, all AVE values exceed the 0.50 as required by Hair et al., in Sutton (2017). The higher the value of the AVE owned by a latent means a higher correlation between the indicators that make up a construct. It can be concluded that, in general, the measurement model developed in this study has good convergence validity. After examining the value of the AVE and CR, next is the Discriminant Validity value, Table 4 shows discriminant validity value every sublatent.

Table 4. Discriminant Validity of Sub - Latent Variables

\begin{tabular}{|l|r|r|l|}
\hline & Executor Role & Facilitator Role & Regulator Role \\
\hline Executor Role & $\mathbf{0 , 8 6 6}$ & & \\
\hline Facilitator Role & 0,422 & $\mathbf{0 , 7 2 9}$ & \\
\hline Regulator Role & 0,489 & 0,754 & $\mathbf{0 , 8 8 1}$ \\
\hline
\end{tabular}




\begin{tabular}{|c|r|r|l|}
\hline & $\begin{array}{l}\text { Economic } \\
\text { Benefit }\end{array}$ & $\begin{array}{l}\text { Environmental } \\
\text { Benefit }\end{array}$ & $\begin{array}{l}\text { Socio- Cultural } \\
\text { Benefit }\end{array}$ \\
\hline $\begin{array}{l}\text { Economic } \\
\text { Benefit }\end{array}$ & $\mathbf{0 , 8 6 5}$ & & \\
\hline $\begin{array}{c}\text { Environmental } \\
\text { Benefit }\end{array}$ & 0,602 & $\mathbf{0 , 7 5 9}$ & \\
\hline $\begin{array}{c}\text { Socio-Cultural } \\
\text { Benefit }\end{array}$ & 0,550 & & $\mathbf{0 , 7 6 5}$ \\
\hline
\end{tabular}

Source: Primary Data, 2016

Table 4 illustrates that all latent variables of sustainable marine tourism and local government roles have discriminant validity. This can be seen by the value in bold is greater than the value of correlation with other sub-latent variables, except sub-latent environmental benefit and facilitator role that have a smaller value than the correlation value with the other sub-latent. Nevertheless, after examining the cross-loading of each latent, no cross-loading was found. It can be concluded that all latent variables have discriminant validity and can be analyzed in the next step.

\subsection{Interpretation of Sub - Model Measurement (Outer Model)}

After examining the measurement model (outer model analysis), the interpretation of the sub-measurement model is complete. The feasibility of a measurement model can be seen from the t-statistical value of loading results, provided that $t$-statistics must be greater than the critical value of 1.96 (2- tailed) and the probability value at the 5 percent significance level (Hussein, 2015:20: Kencana, et al., 2015: 174). The t-statistical value and the opportunity value (pvalue) for the sub-measurement model interpretation were obtained from the bootstrapping process, using 60 cases and 500 repetitions. The path analysis of the sub-model measurement can be seen in Table 5.

Table 5. Interpretation of Sub - Model Measurement (Outer Model)

\begin{tabular}{|l|l|c|c|l|l|l|l|}
\hline Latent & $\begin{array}{l}\text { Sub } \\
\text { Latent }\end{array}$ & $\begin{array}{c}\mathbf{R}^{\mathbf{2}} \\
\text { Valu } \\
\text { es }\end{array}$ & $\begin{array}{c}\text { Path } \\
\text { Coeffici } \\
\text { ents }\end{array}$ & $\begin{array}{l}\text { Stand } \\
\text { ard } \\
\text { Deviat } \\
\text { ion }\end{array}$ & $\begin{array}{l}\text { T } \\
\text { Statis } \\
\text { tics }\end{array}$ & $\begin{array}{l}\text { P } \\
\text { Valu } \\
\text { es }\end{array}$ & $\begin{array}{l}\text { Relationsh } \\
\text { ips }\end{array}$ \\
\hline $\begin{array}{l}\text { The Role } \\
\text { of Local }\end{array}$ & $\begin{array}{l}\text { Regulator } \\
\text { Role }\end{array}$ & $\begin{array}{l}0,77 \\
6\end{array}$ & 0,881 & 0,026 & $\begin{array}{l}34,30 \\
9\end{array}$ & $\begin{array}{l}0,00 \\
0\end{array}$ & Significant \\
\cline { 2 - 8 }
\end{tabular}




\begin{tabular}{|c|c|c|c|c|c|c|c|}
\hline \multirow[t]{2}{*}{$\begin{array}{c}\text { Governm } \\
\text { ent }\end{array}$} & $\begin{array}{l}\text { Facilitator } \\
\text { Role }\end{array}$ & $\begin{array}{l}0,88 \\
4\end{array}$ & 0,940 & 0,018 & $\begin{array}{l}52,60 \\
0\end{array}$ & $\begin{array}{l}0,00 \\
0\end{array}$ & Significant \\
\hline & $\begin{array}{l}\text { Executor } \\
\text { Role }\end{array}$ & $\begin{array}{l}0,42 \\
7\end{array}$ & 0,654 & 0,083 & 7,854 & $\begin{array}{l}0,00 \\
0\end{array}$ & Significant \\
\hline \multirow{3}{*}{$\begin{array}{c}\text { The } \\
\text { Sustainab } \\
\text { ility of } \\
\text { Marine } \\
\text { Tourism }\end{array}$} & $\begin{array}{l}\text { Economic } \\
\text { Benefit }\end{array}$ & $\begin{array}{l}0,72 \\
3\end{array}$ & 0,850 & 0,050 & $\begin{array}{l}16,88 \\
9\end{array}$ & $\begin{array}{l}0,00 \\
0\end{array}$ & Significant \\
\hline & $\begin{array}{l}\text { Socio - } \\
\text { Cultural } \\
\text { Benefit }\end{array}$ & $\begin{array}{l}0,76 \\
1\end{array}$ & 0,872 & 0,025 & $\begin{array}{l}34,62 \\
8\end{array}$ & $\begin{array}{l}0,00 \\
0\end{array}$ & Significant \\
\hline & $\begin{array}{c}\text { Environment } \\
\text { al } \\
\text { Benefit }\end{array}$ & $\begin{array}{l}0,82 \\
9\end{array}$ & 0,911 & 0,023 & $\begin{array}{l}40,05 \\
4\end{array}$ & $\begin{array}{l}0,00 \\
0\end{array}$ & Significant \\
\hline
\end{tabular}

Source: Primary Data, 2016

Table 5 shows all path coefficients of each latent to its reflection sub-latent are significant at $(\alpha) 5$ percent level (2-tailed). The reflective relationship between the variables of the role of local government with the three sub-latent, namely the role of the regulator, the role of facilitator, and the role of the executor as its indicators, these three path coefficients show a significant relationship. In the latent reflective relationship of sustainable marine tourism with its three sub-latent, economic benefit, socio-cultural benefit, and environmental benefit show a significant relationship.

\subsection{Inner Model Analysis}

After the outer model analysis was done, we conducted inner model analysis. This analysis was done because the outer model successfully represented the structure of every latent and its indicators. Structural analysis of the model is performed to ensure that structural models are constructed accurately. Inner model evaluation can be seen from the Goodness of Fit Index (GoF). This GoF value can be calculated using the following equation:

$\mathrm{GoF}=\sqrt{\overline{A V E} \times \overline{R^{2}}}$

In Equation 1 and are the weighted average value of AVE and weighted average value of each endogenous latent on the model (Tenehaus, et al., 2005). After examining the value of GoF is obtained value as much as 0.653 . As the lowest threshold limit is 0.50 , thus the model constructed in this study has a representative ability to explain the latent (exogenous and endogenous) relationships in a structural equation model (Tenenhaus, et al., 2005).

\subsection{Interpretation of Structural Model (Inner Model)}


This analysis also uses a bootstrapping procedure, available in software SmartPLS 3.0 and set no sign changes with 60 cases and 500 samples in the bootstrap setting. The results are shown in Table 6 below.

Table 6. Direct Effects of Each Causal Relationship in the Inner Model

\begin{tabular}{|c|c|c|c|c|c|c|}
\hline $\begin{array}{l}\text { Latent } \\
\text { Compiler }\end{array}$ & $\begin{array}{l}\text { Latent } \\
\text { Endogeneous }\end{array}$ & $\begin{array}{c}R^{2} \\
\text { Valu } \\
\text { es }\end{array}$ & $\begin{array}{c}\text { Informa } \\
\text { tion } \\
\text { Values }\end{array}$ & $\begin{array}{c}\text { Path } \\
\text { Coeffici } \\
\text { ents }\end{array}$ & $\begin{array}{c}P \\
\text { Valu } \\
\text { es }\end{array}$ & $\begin{array}{l}\text { Relations } \\
\text { hips }\end{array}$ \\
\hline $\begin{array}{l}\text { The Role of } \\
\text { Local } \\
\text { Government }\end{array}$ & $\begin{array}{l}\text { The Sustainability } \\
\text { of } \\
\text { Marine Tourism }\end{array}$ & 0.054 & Weak & -0.232 & 0.114 & $\begin{array}{c}\text { Not } \\
\text { Significa } \\
\text { nt }\end{array}$ \\
\hline $\begin{array}{l}\text { The Role of } \\
\text { Local } \\
\text { Government }\end{array}$ & Regulator Role & 0.776 & Good & 0,881 & 0,000 & $\begin{array}{l}\text { Significa } \\
\mathrm{nt}\end{array}$ \\
\hline $\begin{array}{l}\text { The Role of } \\
\text { Local } \\
\text { Government }\end{array}$ & Facilitator Role & 0.884 & Good & 0,940 & 0,000 & $\begin{array}{l}\text { Significa } \\
\mathrm{nt}\end{array}$ \\
\hline $\begin{array}{l}\text { The Role of } \\
\text { Local } \\
\text { Government }\end{array}$ & Executor Role & 0.427 & Fair & 0,654 & 0,000 & $\begin{array}{l}\text { Significa } \\
\mathrm{nt}\end{array}$ \\
\hline $\begin{array}{c}\text { The } \\
\text { Sustainability of } \\
\text { Marine Tourism }\end{array}$ & Economic Benefit & 0.723 & Good & 0,850 & 0,000 & $\begin{array}{l}\text { Significa } \\
\mathrm{nt}\end{array}$ \\
\hline $\begin{array}{c}\text { The } \\
\text { Sustainability of } \\
\text { Marine Tourism }\end{array}$ & $\begin{array}{l}\text { Socio - Cultural } \\
\text { Benefit }\end{array}$ & 0.761 & Good & 0,872 & 0,000 & $\begin{array}{l}\text { Significa } \\
\mathrm{nt}\end{array}$ \\
\hline $\begin{array}{c}\text { The } \\
\text { Sustainability of } \\
\text { Marine Tourism }\end{array}$ & $\begin{array}{l}\text { Environmental } \\
\text { Benefit }\end{array}$ & 0.829 & Good & 0,911 & 0,000 & $\begin{array}{l}\text { Significa } \\
\mathrm{nt}\end{array}$ \\
\hline
\end{tabular}

Source: Primary Data, 2016

From Table 6 we can see the reflective relationship between the variables of local government role with its three sub-latents is significant, where the role of facilitator has the biggest determination coefficient ( 88.4 percent), followed by the role of regulator (77.6 percent), and the smallest is the role of executor (42.7 percent). This indicates that people's perception toward local government role has greater dominance in facilitator role than the role of regulator or executor. This is 
inseparable from the discovery in the field indicating that local government has played a large part in mentoring programs, such as: guide and diving training; financial assistance to Pakraman Village; physical assistance in the form of boats for Pecalang Segara (sea guards); facilitating public education with the establishment of SMAN 2 Gerokgak in Pemuteran Village area; promoting and marketing the marine tourism through Buleleng Dive Festival activities by making Pemuteran the main subject of brochures, event calendar, and tourism map which are distributed by Tourism Office to hotels and travel agents in strategic tourism area of Kuta.

In the latent reflective relationship of sustainable marine tourism with its three sub-latents also show significance, where the biggest coefficient determination $\left(\mathrm{R}^{2}\right)$ is found in the sub-latent of environmental sustainability (82.9 percent), followed by socio-cultural sustainability (76.1 percent), and the lowest, economic sustainability (72.3 percent). This shows that the local community in Pemuteran Village is more beneficial to the environmental benefit than the sociocultural and economic benefits of marine tourism. This is confirmed by the community and can be demonstrated by the condition of coral reefs, compared to when the marine tourism was not developed as rapidly as it is today, cleaning the beach and sea is done routinely, public facilities are more organized, indirectly, also increase community awareness of a sustainable living environment.

The formative relationship shows that the role of local government does not significantly affect the sustainability of marine tourism. It is shown by its coefficient determination of only 5.4 percent. It means that local government roles only affected the sustainability of marine tourism as much as 5.4 percent.

\subsection{Discussion}

The effect of government roles did not significant in realizing sustainable marine tourism although its roles are reflected significantly to its sub-latent (regulator role, facilitator role, and executor role). This lines up e with some findings. The research about participation and local government's role in realizing the quality ecotourism destination at Batur Global Geopark, Kintamani district of Bali, found that the local government role reflected distributive and regulative roles but could not affect the quality of ecotourism at Kintamani, Bali significantly (Mertha, 2015). The other study regarding local government roles and culinary tourism in Kedonganan Village, Bali also found that the effect of government roles was not significant regarding local community satisfaction although distributive role and regulative role proved significantly affect the perception of local people toward government role in implementing sustainability of culinary tourism at Kedonganan, Bali (Merha et al., 2015). As Birkiè, Pilija, \& Šebrek (2014) found, the local government has the irreplaceable role $y$ in the tourism development at the local level, but insufficiently implements the concept of sustainable development. This is due to their lack of knowledge and experience in planning tourism that is based on the principle of sustainability (Birkiè, Pilija, \& Šebrek, 2014; Dartian, 2017). Local governments do not understand what tourism is or how it is run (Mc Kercher, 2003). As several studies have shown, one of the weak points of tourism 
development in a region lies in the ability and knowledge of government, as both are far from adequate. This includes planning, development of tourism programs, regulation, until cross-sectoral coordination (Damanik \& Weber, 2006). Some facts show that the number of tourism planners with a qualified capacity in local government institutions is minimal. Otherwise they more commonly found in big resorts. This is very important because there are still many local government institutions that do not have a master plan for tourism development in their area (Can, Allaedinoglu, \& Turker, 2014).

These notions are in line with Kusworo \& Damanik (2002), who found that the ability of the bureaucracy in the regional tourism offices from 9 regions and city in Bali Province (the island that has a long history of tourism) is still under regions or cities outside Bali. Which are otherwise is classified as "inexperienced in tourism" at the national level such as Cianjur, Subang or even Pare-Pare. This means, the ability of the bureaucracy in Bali regional tourism offices to carry out the planning, implementation and management of tourism development is still limited. So, it can be understood, as local community in Pemuteran confirmed that most government's programs were not a match for the problems faced by the community in Pemuteran Village, and were not continuous, with no assertiveness from the local government in responding to any violations related to marine tourism.

It is important to note that previous studies have only measured the role of local government as regulator and facilitator. This study tries to examine the role of executor also The results show that the role of executor should be conducted by the local government can be seen from the value t-statistics and the value of significant opportunities. Mertha (2015) stated that the local government's responsibility towards the quality of the destination has an insignificant result, that the community has greater expectations for the government as both regulator and facilitator. This view is also in line with the notions of Cavaye (2000) and Swanson et al. (2006), who mentioned the importance of consistent governmental enforcement.

This study found that the sustainability of marine tourism is reflected by economic, socio-cultural, and environmental benefits. As the perception of local community is that the existence of marine tourism in the Pemuteran Village has benefited them. In accordance with Kencana and Mertha (2014), who found that the sustainability of ecotourism in Kintamani reflected the economic, sociocultural, and environmental benefits that the community felt. It is strongly suspected that there are other stakeholder roles affecting the local community's acceptance of these three benefits. This is logical, considering the concept of regression, that a dependent variable (endogenous) is influenced by many other variables (exogenous). Allegedly, five existing stakeholders (UNWTO, 2011:21) ie., the government, industry, NGOs (non-government organization), local communities, and tourists simultaneously play in providing benefits to Pemuteran Village. Interviews with local community leaders found that traditional institution at the Pemuteran Village or Desa Pakraman is the party that maintains the sustainability of marine tourism in their village. According to this study, local governments seem to need a good mediator to coordinate programs that will be instituted to achieve 
the sustainability of tourism. A good mediator in this case, is the traditional institution of Pemuteran Village or Desa Pakaman Pemuteran. In line with UNWTO (2011) stated that community agencies have a very important role in strengthening relations and coordination between stakeholders, and in providing advice to other stakeholders, as they are most understanding of the region.

\section{CONCLUSION}

This study shows that local government has not played a significant role in realizing sustainable marine tourism, although the three roles of regulator, facilitator, and executor are reflected significantly. Among the three roles, That of facilitator is the most represented in Pemuteran Village. Meanwhile, although the role of local government was not significant in realizing sustainable marine tourism, local people of Pemuteran still feel the sustainability of marine tourism in the region. The sustainability of marine tourism in Pemuteran is demonstrated through the economic, social-cultural and environmental benefits that are reflected, significantly in the research model. Environmental benefits are the most represented variables of sustainable marine tourism in Pemuteran Village. It is strongly suspected that there are other stakeholder roles affecting the local community's acceptance of these three benefits. Interviews with local community leaders found that, traditional institution at the Pemuteran Village or Desa Pakraman keeps trying to maintain the sustainability of marine tourism.

The local government must be aware that their roles cannot affect sustainable marine tourism in a significant way. From this viewpoint, we suggest the government reviews their roles in order to match them with community needs. Besides that, The local government initiating the program should not directly work with the community, but coordinate first with other institutions, such as Pakraman Village (traditional institution), because Pakraman Village is considered the most understanding of the condition of society and its territory.

\section{ACKNOWLEDGEMENTS}

The authors wish to thank Dr. I Wayan Mertha, SE., M.Si and Ir. I Putu Eka Nila Kencana, M.T who have provided much guidance and inspiration in the writing of this study.

\section{REFERENCES}

Abdillah, Willy dan Jogiyanto Hartono. (2014). Concepts and Applications PLS (Partial Least Square) for Empirical Research. Yogyakarta: Andi. Brokaj, R. (2014). Local Government's Role in The Sustainable Tourism Development of A Destination.

European Scientific Journal, 10 (31), 103-117.

Birkiè, D, Pilija, I.C, \& Šebrek, J.K. (2014).The Role of Local Government in Planning of Sustainable Tourism of Coastal Destination. Tourism and Hospitality Industry, Congress Proceedings, 16-32. 
Cavaye,J. (2000). The Role of Government in Community Capacity Building.The Role of Government in Community Capacity Building. Research Report, 132 .

Can, Allaedinoglu, \& Turker. (2014). Local Authorities Participation in The Tourism Planning Process. Transylvanian Review of Administrative Sciences, (41 E), 190-212.

Damanik, Janianton dan Helmut F. Weber. (2006). Ecotourism Planning From Theory to Applications. Yogyakarta: Andi Offset.

Dodds, Rachel \& Butler, Richard. (2010). Barriers to Implementing Sustainable Tourism Policy in Mass

Tourism. Tourismos: An International Multidisciplinary Journal of Tourism, 5(1), 35-53.

Drost, Ellen A. (2011). Validity and Reliability in Social Science Research. Education Research and Perspective, 38(1), 105-124.

Dartian, Rahmat. (2017). Knowledge, Attitudes and Behavior of The Local Government Officials of The Island Banggai District Towards Sustainable Tourism Development. Unpublished Thesis, Post Graduate School Universitas Gadjah Mada, Yogyakarta, Indonesia.

Hair, et al. (2010). Multivariate Data Analysis. New Jersey: Prentice Hall.

Hussein, Ananda S. (2015). Business Research and Management Using Partial Least Square (PLS) with

Smart PLS 3.0.Availble at: anandahussein.lecture.ub.ac.id accessed on June 12016.

Hall, Michael C. (2001). Trends in Ocean and Coastal Tourism: The End of The Last Frontier. Ocean and Coastal Management, 1-18.

Heale R. \& Twycross A. (2015). Validity and Reliability in Quantitative Studies. Evidence Based-Nursing, 18(3), 66-67.

Hair, Joseph H, Ringle C.M, Sarstedt, M. (2012). Editorial Partial Least Squares: The Better Approach to Structural Equation Modeling?. Long Range Planning, 45, 312-319.

Indonesia Tourism Ministry. (2016).Priority of Tourism Destination Development 2016-2019. Available at: http://www.kemenpar.go.id. accessed on November 10th 2015

Indonesia Tourism Ministry. (2017). Indonesia Sustainable Tourism Award. Report Winner of Indonesia Sustainable Tourism Award. Available at: www.kemenpar.go.id/asp/ accessed on June 1th 2018.

Kencana, Eka N, et al. (2015). Model Structural Equation of Public Satisfaction Level on Quality of Mandara Toll Road Service. E-Journal of Mathematics, 4 (4), pp. 169-175. 
Kencana, Eka N dan I Wayan Mertha. (2014). People Participation As Social Capital For Realizing Sustainable Ecotourism. Research Report of Dipa Sekolah Tinggi Pariwisata Nusa Dua Bali.

Kusworo, Hendrie Adji \& Damanik, Janianton. (2002). Development of Regional Tourism Human Resources: Policy Agenda for Policymakers. Politic and Social Science, 6(1), 105-120.

McKercher, Bob. (2003). Sustainable Tourism Development-Guiding Principles for Planning and Management. Presentation to the National Seminar on Sustainable Tourism Development

Bishkek, Kyrgyzstan, November 5 - 9 .

Mertha, I Wayan. (2015). Community Participation and Government's Role in Achieving Quality Tourism Destination (Study at Batur Global Geopark Kintamani). Unpublished Dissertation (doctoral thesis), Postgraduate of Udayana University, Economic Science Program, Denpasar, Bali.

Mertha, et al. (2015).The Structural Model for Evaluating The Role of Local Government in Culinary Tourism.International Journal of Engineering Sciences and Research Technology, 4(12), 294-301.

Ogechi O.C. \& Ibojekwe P.A. (2012). Local Government and Responses to Sustainable Tourism Development in Nigeria: A Study of Local Government Authorities in Imo State. Hospitality, Leisure, and Tourism Management, Yaba Collage of Technology, Yaba Lagos, Nigeria.

Potential of Pemuteran. (2012). Available at disbudpar.bulelengkab.go.id accessed on November 10th 2015.

Sarstedt et al. (2016). Estimation Issues with PLS and CBSEM:Where the Bias Lies. Journal of Business Research, 69, 3998-4010.

Sutton, Christine et al. (2017). Secondary Agency Conflicts: A Synthesis and Proposed Measurement Model. Long Range Planning, 30, 1-16.

Swanson et al. (2006). The Field of Law Enforcement. United States: Jones and Bartlett Learning.

Tenenhaus, M., Binzi, V.E., Chatelin. Y.M. \& Lauro, C., (2005).PLS Path Modeling. Computational

Statistics \& Data Analysis, 48, pp.159-205.

Tourism Destination Program of Bali Tourism Institute. (2015).Report of Destination Field Research Existence and Role of Marine Tourism for Local Community in North Bali. Seminar Publication, Sekolah Tinggi Pariwisata, Nusa Dua Bali.

United Nation World Tourism Organization. (2011). Tourism Towards 2030. Available at:

http://media.unwto.org accessed on November 10th 2015. 
United Nation World Tourism Organization. (2017). Tourism Highlights. UNWTO Publications. Available at: http://www.e-unwto.org/doi/book accessed on June 1th 2018.

United Nations Environment Programme (UNEP). (2003). Tourism and Local Agenda 21: The Role of Local Authorities in Sustainable Tourism. First Edition. France: United Nations Publication.

World Travel \& Tourism Council. (2017). Travel \& Tourism World Economic Impact. A Report on Economic and Social Contribution of Travel and Tourism. United Kingdom: World Travel \& Tourism Council. 